\title{
Catch Me When I Fall! Resiliency, Freedom and Black Sisterhood in the Academy
}

\author{
Delores V. Mullings \\ Memorial University of Newfoundland and Labrador \\ dmullings@mun.ca \\ Amoaba Gooden \\ Kent State University \\ agooden@kent.ca \\ Elaine Brown Spencer \\ CEO Kaleo Production \\ kaleoproduction@gmail.com
}

\begin{abstract}
Many Black women academics feel caged in their 'subject position[s]' within the academy. They are challenged by lack of opportunities and mentorship, isolation, explicit racism, microaggressions and stereotyping. Despite the ways in which their bodies are marked by racist sexism, Black women faculty take on an inordinate amount of unrecognized, differentiated labour and service work in the academy. They tend to assist other racialized colleagues, graduate and undergraduate students to achieve academic success. There is a common thread of resiliency among these women who successfully navigate their paths in the academy through applications of the concept of Radical Black Academic Sisterhood. This is an interpretive praxis that utilizes both an oppositional stance and creates brave spaces to deal with experiences of being caged.
\end{abstract}

Keywords: Black women academics, Black women faculty, Black sisterhood

\author{
A free bird leaps \\ on the back of the wind \\ and floats downstream \\ till the current ends \\ and dips his wings \\ in the orange sun rays \\ and dares to claim the sky. ${ }^{1}$
}

(Angelou, M., 1994, p. 194)

Globally, Black women face the pervasive violence associated with systems of domination which mark Black bodies as less than deviant, hypervisible and ironically, simultaneously invisible. These systems of domination -- white supremacy, sexism, racism and

\footnotetext{
${ }^{1}$ We weave Dr. Maya Angelou's poetry called Caged bird throughout the article by using excerpts of the poem to introduce each section and to support our argument overall. We relate to Angelou's description of the Caged bird as it reflects our own experience of racialized and gendered discrimination. However, and more importantly, Caged bird highlights our determination and resilience to never acquiesce to institutional domination.

Cultural and Pedagogical Inquiry, Summer 2020, 12(1), pp. 91-104

ISSN 1916-3460 @ 2020 University of Alberta

http://ejournals.library.ualberta.ca/index.php/cpi/index
} 
classism -- are part of a long colonial history of violence, and their impacts on North American institutions of higher education are considerable (Stein, 2018). For Black women faculty (BWF) in Canada and the US, these multiple forms of oppression are embedded in the policies, procedures and processes of academic life and negatively shape their personal and professional lives, often leaving them feeling caged in their 'subject position[s]' within academic institutions (Matthew, 2016, p. 16; see also Evans, 2007; Cruz et al., 2016).

Institutions of higher learning use an implicit, and sometimes explicit social contract to maintain a gendered and racial social order in the hiring, promotion, and maintaining of white bodies and ideals. As a consequence, the hallways, private offices, classrooms, tenure and promotion processes, hiring committees and evaluation boardrooms are littered with caged bodies, clipped wings, and/or the blood and bones of Black women. Yet, despite the ways in which racism and sexism exclude and/or mark Black women's bodies and knowledge production, there is often a common thread of hope and resiliency among many as they navigate their path in the academy. Tackling the intellectual investment that supports a continuation of a repressive gendered and racialized system, BWF engage in knowledge production and social action. In addition to taking on an inordinate amount of service work and other labour differentials, we tend to assist other racialized faculty and students in an effort to create social change at their institutions (Harely, 2007; Harris 2008; Stein, 2018).

Many of these Black and Brown women draw strength from a global Black Radical Tradition which include the voices of scholars, artists and activists such as Maya Angelou, Rosemary Brown, W. E. B. Dubois, Mary Church Terrell and Burnley Rocky Jones. These revolutionaries have all noted that despite the ways in which institutionalized sexism, racism and other forms of oppression impact marginalized individuals, there is a strong historical legacy of resistance and resilience. Drawing on this Black Radical Tradition, the authors have framed a concept called Radical Black Academic Sisterhood (RBAS) - an interpretive praxis that utilizes both an oppositional stance to resist marginalization and the use of brave spaces to ensure professional and personal success. An act of kinship, RBAS is a reflexive, action-oriented, interventionist and relational praxis that provides social and emotional support to Black women and other marginalized individuals as they navigate and resist systems of oppression in the academy. RBAS recognizes the challenges that BWF face in the academy and emphasizes the forming of alliances of sisterhood with other Black and Brown women. These relationships can help Black women transcend the debilitating stench of racism, heteronormativity and sexism. As well, these relationships can often provide a space for Black women to be vulnerable, talk, support others, get support, and "just be" without judgment, or the pressure to conform to dominant expectations.

In this paper, three BWF, two of whom reside in Canada and the third, who resides in the USA, discuss how RBAS can be used to survive and sometimes thrive under hostile conditions. Recognizing that Black women, regardless of class, gender, nationality, sexual orientation, (dis)ability and spiritual practices have a common racialized experience, our framing of RBAS is informed by the Critical Race Feminism framework of the Ekwe Feminist praxis (Cruz et al., 2016) and by Patricia Hill Collins' Black Feminist Thought (Hill Collins, 2000). Both the Ekwe Framework and Black Feminist Thought emerged out of a Black Radical Tradition and are grounded on a liberatory epistemological understanding of resilience and resistance. The authors use their philosophical underpinnings of advocacy and resilience to frame RBAS as a way to redress racialized and gendered institutional violence.

Cultural and Pedagogical Inquiry, Summer 2020, 12(1), pp. 91-104

ISSN 1916-3460 @ 2020 University of Alberta

http://ejournals.library.ualberta.ca/index.php/cpi/index 
In honor of Maya Angelou's, I Know Why the Cage Bird Sings, we use the concept of being caged as a trope to bring meaning to the ways in which BWF experience, at the personal level, gendered and racialized systemic discrimination which often include isolation, lack of opportunities, lack of mentorship and microaggressions that alienate, silence and erase (Cruz et al., 2016; Evans, 2007; Matthew, 2016; Muhs, 2012). The article is organized as follows: (1) A discussion of the methodological and theoretical framework; (2) A summary of the literature review; (3) Storytelling from the perspectives of the authors; (4) An exploration of story linkages, and (5) The identification of strategies of resilience to combat institutional race and gender discrimination in the academy. The chapter concludes with suggestions for the informal formation of RBAS relationships in Canada and the United States.

\section{Methodology and Theoretical Framework}

But a bird that stalks down his narrow cage

can seldom see through his bars of rage

his wings are clipped, and his feet are tied

so he opens his throat to sing

(Angelou, 1994)

You know Amoaba, I tried and I tried...I had so many BBQ's, lunches, breakfasts, dinners and activities of all kinds trying to make friends and form community.

I had never had any problems making friends or having a community around me before.

(Delores, 2018)

The methodological approach we find most meaningful in framing RBAS is Black Feminist Autoethnography (BFA), as proposed by Griffin (2012) in her seminal article, I AM an Angry Black woman. Griffin integrates autoethnography (AE) with Hill Collins' (2002) Black Feminist Thought (BFT), and offers BFA as a theoretical and methodological approach for BWF to narrate their lived experiences. Griffin (2012) argues that Black women's stories and narratives must be centered in research and scholarship to avoid the erasure of our voices. Advancing Griffin's work, Cruz, et al. (2016) argues that BFA "highlight struggles common to Black womanhood without erasing" our complexities or essentializing our experiences. BFA positions Black women to strategically confront systems of oppression and allows us, to narrate our systemic marginality, resilience and self-empowerment while situating our experiences alongside other Black women (Cruz, et al., 2016, p. 80).

In addition to the above, and given the racialized and gendered experiences of Black women, we also employ two theoretical approaches in our framing of Radical Black Academic Sisterhood: Black Feminist Thought (BFT) and the Ekwe Collective Praxis framework. Black Feminist Thought emerges out of the historical and material conditions that shape Black women's lived experiences (Hill Collins, 2002). Hill Collins (2002) articulates BFT as "a Black women's group standpoint regarding experiences associated with intersecting oppressions" (p. 28). Central to BFT is the understanding that Black women strive to cultivate safer communities under subjugating contexts, work to promote empowerment among Black women and attempt to improve social conditions for all. BFT centers Black women in their own life experiences while

Cultural and Pedagogical Inquiry, Summer 2020, 12(1), pp. 91-104

ISSN 1916-3460 @ 2020 University of Alberta

http://ejournals.library.ualberta.ca/index.php/cpi/index 
also acknowledging the ways in which Black women have engaged in coalition building for racial and gender equity.

The second theoretical framework, The Ekwe Collective, extends BFT and is a radical framing of Black/Brown sisterhood which expands the US-based understanding of Black feminism. The Ekwe, a sisterhood of Black and Brown academics and their children, was formed when six women, who needed a sisterhood community, gathered to carve out brave spaces to reflect and discuss their experiences, both in the academy and in their personal lives (Cruz et al., 2016). Out of their conversations and reflections, the women developed the Ekwe Collective framework, a praxis which includes both reflection and action and is grounded in the understanding that it the historical experiences and consciousness of Black women that shape their collective consciousness. This consciousness foregrounds Black women's intellectual and creative production (Cruz, et al., 2016; Hill Collins, 2002), and is informed by Black women's membership in "marginalized communities at the intersections of gender, race, ethnicity, class, and nationality" (Cruz, et al., 2016, p. 78). Both BFT and the Ekwe Collective offer tools to navigate interlocking systems of domination to overcome barriers and create resilient communities (Cruz, et al., 2016, p. 20; Hill Collins, 2002; McLane-Davison, Quinn, Hardy \& Smith, 2018, p. 20). Using these tools, we have mapped out RBAS, which ultimately aims to craft an understanding of how to negotiate, navigate and care for ourselves and other marginalized Black and Brown women in the academy.

\author{
Literature Review \\ The caged bird sings \\ with fearful trill \\ of the things unknown \\ but longed for still \\ and his tune is heard \\ on the distant hill \\ for the caged bird \\ sings of freedom
}

(Angelou, 1994)

From hiring practices to racialized workplace policies, practices and procedures, the experiences of BWF in institutions of higher learning are a microcosm of the wider society. Diggs et al. (2009) confirms that institutional anti-Black racism is embedded in the hiring and retention process of Black women faculty (BWF). In Canada, only $2.0 \%$ of university faculty are Black, and Black women are overrepresented in short-term, contract precarious academic positions, and are not often promoted to the ranks of senior administrators (The Canadian Association of University Teachers, 2018; Henry, Dua, James, Kobayashi, Li, Ramos, \& Smith, 2017; Smith, 2018). In the USA, while Black women are the most numerous of racialized faculty in institutions of higher learning, they accounted for only $3.3 \%$ of full-time tenured or tenured track faculty (National Center for Education Statistics, 2000).

In addition to the above, numerous scholars (Diggs, Garrison-Wade, Estrada, \& Galindo, 2009; Evans, 2007; Gooden \& Crawford, 2016; Harley, 2008; Sudbury, 2002; Mullings \&

Cultural and Pedagogical Inquiry, Summer 2020, 12(1), pp. 91-104

ISSN 1916-3460 @ 2020 University of Alberta

http://ejournals.library.ualberta.ca/index.php/cpi/index 
Mullings, 2013; Razack, 1998), in both Canada and the US, have documented Black women's experiences of systemic domination. Systems of interlocking violence based on subjectivities such as race, class, sexual orientation, religion, spirituality, age, health and gender manifest as overt discriminatory practices and microaggressions (Diggs, Garrison-Wade, Estrada \& Galindo, 2009; Thomas \& Hollander, 2001; Turner, 2002; Gregory, 2001; Schiller, 2000) which are "designed to impede [Black Women's] progress because of their embodiment of a racialized and gendered identity" (Harris, 2007, p. 55).

Further, BWF are overly scrutinized and routinely assessed at a different and higher standard than their white counterparts. Often alienated in their academic units, BWF are forced to constantly define and defend their professional identity alongside their race and gender, they are excluded from departmental and institutional collaborative research projects, and their qualifications are questioned or devalued by white students, faculty and administrators alike who routinely question their intellect, knowledge, credibility, legitimacy and authority (Chaisson, 2004; Williams, 2001; Harris, 2007; Massaquoi, 2004; Shealey, McHatton, McCray \& Thomas, 2014). Evans (2007) suggests that "Black women, while suffering a distinct set of educational and intellectual stereotypes, are...subject to...extraordinary scrutiny" (p. 134). She further posits that "this scrutiny takes place without critical analysis of the centuries of debilitating oppression" that Black women have had to overcome (p. 134). Evans (2007) along with Harris (2007), point out that this is stressful and exhausting and has a negative impact on the health and well-being of Black women academics. They are scrutinized and surveilled to ensure that their perceived radicalness does not negatively affect the university and challenge the status quo (Harley, 2008; Thomas \& Hollenshead, 2001). The above often places "additional pressures on BWF that go beyond the standard requirements associated with teaching, research and service" (Diggs, Garrison-Wade, Estrada \& Galindo, 2009, p. 317).

While Black women's way of knowing is positioned as antithetical to the academy, their intellectual legitimacy is often called into question. Furthermore, because of dominant academic members' use of continuous surveillance tactics and practices, Black women academics are treated as trespassers. Ironically, they are also entrusted with sensitive and important service work and are often times expected to be "maids of academia" (Harley, 2008). Harley (2008) equates this kind of service work to that of household maids who keep the home (university) running smoothly while receiving minimal remuneration or recognition. Stereotyped as incompetent, harsh or uncaring, BWF often carry a burden of service that other groups, such as white males, do not. According to Hill Collins (2002) and West (1995), the role of the "Mammy," or in other words, mothering and parenting in the academy, comes with personal consequences and risk to the health of BWF. BWF are sought out to serve as social justice advocates and change agents; serve on race and gender-related committees; provide leadership on diversity and inclusion issues; teach diversity courses; mentor Black, Indigenous and racialized students; assume low-level administrative responsibilities, and do activities that are not credited in the promotion and tenure process (Cobayashi, 2009; Harley, 2008; Henry \& Tator, 2009; Hill, 2000). This kind of service can have a negative impact on self-care time, in addition to leaving little time for creative and productive endeavours.

And, while BWF members provide an inordinate amount of service to the university community, they are still expected to teach, research, write and publish at similar or better rates than their white colleagues who do not have the same extensive service responsibilities (Adeleke, 2010). In addition, BWF often lack role models and mentorship which leaves them struggling in

Cultural and Pedagogical Inquiry, Summer 2020, 12(1), pp. 91-104

ISSN 1916-3460 @ 2020 University of Alberta

http://ejournals.library.ualberta.ca/index.php/cpi/index 
ways that their white counterparts do not (Wane, 2012). Consequently, BWF often "suffer from a form of race fatigue - the syndrome of being over extended, undervalued, unappreciated" (Harley, 2008, p. 21).

\author{
Raising our Voices \\ The free bird thinks of another breeze \\ and the trade winds soft through the sighing trees \\ and the fat worms waiting on a dawn bright lawn \\ and he names the sky his own
}

(Angelou, 1994)

\title{
Delores' Story
}

I was excited to begin my new journey as a tenure-track, associate professor in a small urban centre, in Eastern Canada, at a school of social work. Although I was leaving my family behind, except for my 14-year-old daughter who travelled with me, I felt like a free bird in search of fat worms. However, I quickly saw how anti-Black racism would shape my experiences in the academy. For example, in response to a suggestion that I made during a meeting, a colleague said: "your radicalness won't work here; this is not Ontario." She stated that my ideas of transformative decolonizing pedagogy were "hogwash" and that I needed to check myself. I realized that my colleague was attempting to clip my wings. I was shaken with fear so I called a Black sister for support and we strategized a way forward.

The following semester, another colleague summoned me to her office to admonish me about the students' negative characterization of me which she had gathered from meeting with them at their request. I explained to her my experiences of anti-Black racism and microaggression in the same class. She dismissed my concerns and suggested that students are "just kids" and that they want to do well so I should "just pass everyone." I reached out to a sister circle to discuss classroom strategies.

Being attacked feels common place for me in academe. Such was the case when I tried to create a space for students to dialogue with each other during a tense discussion about racism and colonialism. I left the classroom for 30 minutes so that students could talk together. When I returned, the students were silent and less engaged than before I left. I maintained the silence and finally one of the three white men in class spoke on behalf of others indicating a dislike and discomfort with a number of things, including my attitude and tone of voice. I listened to their suggestions about the phrases and behaviours that they would prefer I use to communicate with them. Rather than reflecting on the entangled issues of race and colonization, the students had used the time to assassinate my character. I was deeply disappointed and felt scarred. I was also angry that the work, commitment and trust that I gave to the students did not materialize into transformative learning. I called a sister friend to talk about the experience and discussed it in a RBAS sister circle at a conference.

As I was adjusting to my new life, I was concerned about my teenage daughter. I watched helplessly as she wilted. I was sickened by her stories of whiteness, ignorance, delegitimization as Canadian and a steadily diminishing self-confidence that gave her permission to say "Mom, Cultural and Pedagogical Inquiry, Summer 2020, 12(1), pp. 91-104 ISSN 1916-3460 @ 2020 University of Alberta http://ejournals.library.ualberta.ca/index.php/cpi/index 
you know that I can't be a lawyer. I'm not smart like the Olson twins." I realized that she was caged and bounded. This was not the same child that knew that she was "brilliant and smart" before she could speak because I wrote her a poem reminding her of her gifts which I read to her nightly. She later suffered a blow when all five of her closest friends made a decision that excluded her from an activity that they had planned. She found out when she saw the announcement on Facebook; she was devastated and completely isolated. We are used to being close to our large extended family but in our new home we had no one, so I tried to build a community for my daughter and myself.

I organized events at my home and invited acquaintances and colleagues from my department for four years. One Thanksgiving, I did not host an event and we did not receive an invitation to supper, so my daughter and I had supper alone at a restaurant. Similarly, I tried networking for two years to gain entry into community spaces and yet, I only gained entry into the two spaces that racialized people managed. White colleagues in my school and across the university have never collaborated with me except when I extend the invitation. A senior administrator regularly suggested that I am "a one-trick pony" who only talks about racism. I wonder if the lack of invitation is motivated by my race-focused scholarship. I suffered community, and professional exclusion and isolation which resulted in intense loneliness. My participation in and commitment to sister circles has been life-changing for me.

\section{Amoaba's Story}

I am an African Canadian Caribbean immigrant woman living and working in the United States. Every day I resist being caged! I teach in a Department of Black Studies at a predominately White Institution. While a relatively racially progressive department, the unit I work in has reinscribed its own lines of marginalization. Born out of a Black Radical Tradition which relied heavily on a patriarchal vision of liberation, the department has excluded, silenced, produced and reproduced its own forms of racial and gender violence. While I understand these things to be institutionalized, I experienced them as Cobayashi (2009) highlights, at the level of the individual. In my department, I experienced Black patriarchy, cultural stressors, academic bullying, microaggressions, and sexism. Outside the department, I experienced racialized sexism and isolation.

As an untenured faculty member, a series of incidents occurred that left me shaken. Someone searched my office; my interim chair came to my home uninvited one night; my parenting practices and professional obligations were challenged when a senior faculty member informed me that he once left his child alone because of work responsibilities, suggesting I do the same; and a male colleague told me that I reminded him of his wife. It was also suggested that I could not be trusted because I was friendly with white folks. I was also initially infantilized by being referred to as young and "too" nice to be an advocate for racial change.

Outside my department, my isolation was also reinforced. I was one of two Black faculty that was hired that year and I was one of the few Black female tenure-track faculty on campus. During my third year, a senior Black female faculty member outside of my department accused me of plagiarism and while the charges were dismissed, it scared me and frankly, it initially clipped my wings. Inside and outside my department, my outsider status was reinforced; I was an immigrant and it was suggested on multiple occasions that my experiences as both Caribbean and Canadian meant that I did not understand "real" American racism.

Cultural and Pedagogical Inquiry, Summer 2020, 12(1), pp. 91-104

ISSN 1916-3460 @ 2020 University of Alberta

http://ejournals.library.ualberta.ca/index.php/cpi/index 
In my personal life, I had a spouse who could not find work and who had sacrificed his business so I could live my liberatory dreams of influencing society through teaching. I had two children under the age of six, including a six-month old nursing baby, and an already exhausted body. Throughout my first few years as a faculty, I suffered from guilt, lack of self-care and isolation which impacted my health. At the end of one year, while travelling for a family vacation, to my embarrassment, I was forced to ride a motorized airport transport because my exhausted legs failed and were unable to carry my equally exhausted body.

Despite these challenges, I remained. But I was professionally lonely and isolated. To survive, I turned not only to Black feminist literature to remind and inspire me about the spirit and legacy of resilience in Black women's lives, but I also turned to the life histories of extraordinary women in my own life - my mother and grandmother. Both of these women, who had little formal education, had conditioned me to turn to the legacy of freedom and resilience to craft a space for my own survival.

I grew up with the free spirit and strength of my paternal grandmother who worked as a healer and spirit woman in her community, and who cared for me and my siblings when our parents migrated to Canada. I grew up with a mother who, after migrating, forged friendships with women who could be her eyes in the community when she was at work; eyes that made sure we did not stray too far from home. I watched my mother use her fear, pain and disappointment, brought on by anti-Black racism and sexism to generate resilience (Boylorn, 2017). I watched her return to school, to earn her high school diploma, when she realized that she needed a formal education so she would not be caged in the workplace. I watched her strive, seek freedom, even in the face of my father's emotional abuse because she left a job where her manager was abusive and exploitative. I learned from my grandmother and my mother to form sisterhoods, spirit teams, feminist collectives and accountability groups that would hold me up. I currently participate in multiple sister circles such as the Ekwe Collective and Black Radical Sisterhood groups because these groups hold me up and speak back to the marginalization Black women face in the academy.

\section{Elaine's Story}

I was riding the trade winds - overjoyed to get the opportunity to teach at a large urban Canadian University given the anti-Black racism that I experienced as a student. As a Black Afro-Caribbean Canadian woman in academe, I occupy this liminal space as a faculty member with five degrees including a PhD; however, my part-time status renders me overly visible, simultaneously invisible and illegitimate to students and colleagues. My sense of belonging and legitimacy is always questioned in the classroom and the halls of academe.

Undergraduate students frequently exert their power over me by challenging my authority; they demand and are granted private meetings with full-time faculty administrators to discuss my classroom management style and abilities without ever addressing their concerns with me first. I frequently receive emails from administrators declaring, "I have met with some of your students"; "can you send me a sample of your course outline"; "we have some concerns from students"; "students feel that you don't give them enough time to do their assignments" and "could we schedule a meeting. We have complaints from students about the course." In those instances, my feet are tied temporarily. In response, I call other Black women mentors for support and we strategize and draft responses to such emails together.

Cultural and Pedagogical Inquiry, Summer 2020, 12(1), pp. 91-104

ISSN 1916-3460 () 2020 University of Alberta

http://ejournals.library.ualberta.ca/index.php/cpi/index 
I often ground myself with a poignant memory of one of my professors saying to me "Elaine, I see you going all the way to a PhD one day." The racialized professor, who encouraged me to complete my $\mathrm{PhD}$, came at a time when I made a decision to end my studies as an undergraduate student because I grew weary of challenging the professors and other students in all my classes about racism. Her support exemplified the need for mentorship at all levels of Black women's academic experience (Thomas \& Hollenshead, 2001) to cultivate success, in spite of the experiences, of anti-Black racism that can derail ones' path to success. I continue to seek out mentorship opportunities and support other Black sisters at conferences, book launches, and barbecues to strategize around teaching pedagogy, course management and family challenges. Connecting with like-minded sisters (Thomas \& Hollenshead, 2001) continues to be part of my practice as an academic, because our lives are not limited to the academe. Without these sisterhood connections, my community would be small and my opportunity for success diminished.

My Jamaican father constantly reminds me of the life of poverty he left behind and how proud he is of me and that I must do everything in my power to "keep my job!" Though I love and appreciate my father's support, he is unable to help me navigate the challenges that materialize from within academe. Yet, his constant encouragement echoes the sacrifices of immigrant families who migrated to Canada in search of "better" opportunities for their children and future generations. Managing these two realities of the visible/invisible part-time academic and recipient of a "better opportunity," in the eyes of my father, speaks to the conflicting realities that come with the Afro-Caribbean experience. The year that my mother died, it was extremely difficult to be in the classroom. However, having an outlet to speak with my sister-professor to process my grief was life changing. These discussions allowed me to refuel, reflect and appreciate the people I love. Grounding my work in various aspects of our daily lives is a part of my Black sisterhood and it is important that our lives are not circled around academe alone.

\title{
Enacting the Praxis of Radical Black Academic Sisterhood
}

\author{
But a caged bird stands on the grave of dreams \\ his shadow shouts on a nightmare scream \\ his wings are clipped and his feet are tied \\ so he opens his throat to sing
}

(Angelou, 1994)

\begin{abstract}
I realize that I did not want to do this by myself...I was isolated...the walk is so much easier with radical sisters by my side
\end{abstract}

(Amoaba, 2019)

As noted previously, post-secondary institutions are hostile colonial territories predicated on structural violence which marginalize Black and Brown women with a constant onslaught and bombardment of visible and invisible cannons (Lindholm, 2003; Zabrodska \& Kveton, 2013). The author's narratives demonstrate that Black women are in a precarious position in the academy; isolated, invisible and hypervisible they exist at the intersections of gender and race. According to Hill Collins (2002), Black women who engage in "reclaiming and constructing Black women's knowledge often point to the politics of suppression..." (p. 3) which to some

Cultural and Pedagogical Inquiry, Summer 2020, 12(1), pp. 91-104

ISSN 1916-3460 @ 2020 University of Alberta

http://ejournals.library.ualberta.ca/index.php/cpi/index 
degree, is what all three authors speak of in this article. The authors' personal narratives are some of the ways in which Black women are utilizing a resiliency framework, Radical Black Academic Sisterhood (RBAS), to write themselves into the story of the academy as they resist erasure and re-imagine belonging from a radical Black feminist positioning.

Foregrounding resistance and resilience, RBAS centers recovery of power, respect and dignity, therefore positioning spiritual, creative and intellectual inspiration as a necessity in social justice work. The RBAS concept which, as indicated above, is informed by the work of Griffin (2012), Hill Collins (2002) and Cruz et al. (2016) is operationalized as a reflexive, actionoriented, interventionist and relational praxis. Hence, RBAS is a thinking, acting, intervening and relating framework. The authors use their experiences: (1) to frame telling as a self-reflective act embedded in activism and self-determination, (2) to push back against institutional practices of racial and gendered hostility, (3) to keep Black and Brown bodies safe, and (4) to keep dreams alive. Therefore, enacting RBAS is an attempt to break free of institutional cages that foster surveillance and isolation, and a prompt to rest, to claim and reclaim our spaces as we reenergize ourselves in our struggles to thrive in a symbolic racial and gendered battlefield.

As demonstrated above, RBAS circles are fluid and are created to carve out spaces for Black and Brown women to problem-solve and strategize on how to address, respond to and overcome institutional challenges, professional dilemmas and the personal struggles that we face. For example, we support each other by talking about professional and personal challenges, including systemic discrimination, microaggressions and isolation at work; discuss grant applications, classroom management, caregiving responsibilities and tensions in intimate relationships. All three of us have created spontaneous sister circles at conferences to discuss our experiences and to strategize on moving forward. We have cried out of hurt, sadness, fear and solidarity when we hear stories of our sisters' academic marginalization and the ways in which they are surviving and thriving in what is akin to a war zone.

RBAS recognizes that mentorship within academic units is important to help BWF navigate the nuances of institutional expectations, as well as formal and informal policies, practices and procedures (e.g., tenure and promotion). A lack of mentorship means that BWF will need to seek support and academic partnership outside their departments and institutions. Since BWF scholarship is often uniquely race and gender-based, opportunities for collaboration within units maybe limited (Gregory, 2001; Wayne, 2012). As such, RBAS encourages collaboration. We particularly understand Charmaine Nelson's (2012, para. 2) argument when she said: "I'm it, the only one" in reference to being the only Black faculty member in art history, in a Canadian university. Similar to Charmaine, Amoaba and Delores are the only Black Canadian women in their respective departments. Being the only one is not uncommon but it can be isolating, for many reasons, as Amoaba has indicated in her narrative. Therefore, in addition to mentoring, networking is also inherent in RBAS. It is an essential step to creating communities to participate in, and as well, give and receive support. A lack of community creates isolation for BWF, particularly in spaces where Blackness is unwelcomed and/or essentialized.

RBAS avoids romanticizing or essentializing the idea of Black sisterhood. While it offers support and alternative possibilities, the praxis supports the unlearning of harmful patterns of behavior. We know that the Black sisterhood space, though it sings of freedom, is not universal, and it may not work for all Black women. However, we assume that Black women are

Cultural and Pedagogical Inquiry, Summer 2020, 12(1), pp. 91-104 ISSN 1916-3460 ( 2020 University of Alberta http://ejournals.library.ualberta.ca/index.php/cpi/index 
marginalized and need support to successfully navigate the harsh realities of life. Therefore, this space is consistently and persistently intentional with specificity and commonality -- spiritual, gendered and geographical. It is offered as a fluid and working vision to Black and Brown women to remain open and encourage flexibility to other sisters' ideas, to be fiercely committed to a holistic experience. Furthermore, it is offered as a space for healing and for spiritual, physical and emotional support.

\title{
Strategies and Conclusion
}

\author{
The caged bird sings \\ with a fearful trill \\ of things unknown \\ but longed for still \\ and his tune is heard \\ on the distant hill \\ for the caged bird \\ sings of freedom.
}

(Angelou, 1994)

\begin{abstract}
I was so stressed, not knowing what to expect when I got to class.
Thank God you were there for me as always.
\end{abstract}

(Elaine, 2019)

The authors recognize the sorrow and longing embedded in Angelou's (1994) phrase, "fearful trill of things unknown but longed for still" (p. 194), and offer RBAS as a risky, challenging, messy and painful praxis that pushes Black and Brown women to care for themselves and others as they resist oppression. RBAS acknowledges the importance of vulnerability most notably in the ways Black women are able to embrace the unabashed nature of being able to unveil our aspirations, hurts, excitement, passion and celebrate the differences in our cultural, sexual, religious and spiritual ways of being. We listen, cry, hug, love, support, pray, challenge and disagree, and are committed to a RBAS praxis in spite of and because of our life circumstances.

The narratives shared by the authors in this paper re-imagine belonging in the academy and push for a redress to institutionalized policies, procedures and processes that marginalize, isolate and erase the bodies of BWF. The authors urge Black and Brown women to activate the principles embedded in RBAS by strategically positioning themselves to disseminate their work together at conferences, at meetings in private spaces and public spaces, to use social media and other multimedia technology sites (zoom, skype, facetime) to connect, write, and support each other. Black and Brown women should cite and disseminate each other's scholarship; work collaboratively across distance as research partners, co-author and review manuscripts; mentor each other through discussions of survival strategies such as reframing our experiences, classroom, course and administrative management. An RBAS space is fluid and should assist marginalized women in dipping their wings and soaring in the skies!

Cultural and Pedagogical Inquiry, Summer 2020, 12(1), pp. 91-104

ISSN 1916-3460 () 2020 University of Alberta

http://ejournals.library.ualberta.ca/index.php/cpi/index 


\section{References}

Adeleke, T. (2010). Theoretical discourse on the challenges of Black intellectuals in post-modern America. In N. Basov, J. F. Simet, J. van Andel, S. Mahlomaholo \& V. Netshandama (Ed.), The Intellectual: A phenomenon in Multidimensional perspective (pp. 21-32). Freeland, OX: Interdisciplinary Press.

Angelou, M. (1994). Caged bird. The complete collected poems of Maya Angelou (pp. 194-195). Toronto, ON: Random House.

Baez, B. (2000). Race-related service and faculty of color: Conceptualizing critical agency in academe. Higher Education, 39(3), 363-391.

Boylorn, R. (2017). Sweetwater: Black women and narratives of resilience, revised edition. Peter Lang Incorporated, International Academic Publishers.

Canadian Association of University Teachers. (2018). Diversity \& equity among Canada's postsecondary educating teachers. Retrieved from: https://www.caut.ca/sites/default/files/caut_equity_report_2018-04final.pdf

Carter, D. J., \& Wilson, R. (1993). Minorities in higher education (11th Annual Report). Washington, DC: Office of Minority Concerns. American Council on Education. Retrieved from: https://eric.ed.gov/?id=ED363250

Chaisson, R. R. (2004). A crack in the door: Critical race theory in practice at a predominantly white institution. Teaching Sociology, 32(4), 345-357.

Chavez, M. S. (2012). Autoethnography, a Chicana's methodological research tool: The role of storytelling for those who have no choice but to do critical race theory. Equity \& Excellence in Education, 45(2), 334-348.

Cruz, J. M., Okoh, O., Blind Review, A., Spates, K., Elue, C. A., \& Rousseau, N. (2016). The Ekwe Collective: Black feminist praxis. Departure Critical Qualitative Research, 5(3), 77-100.

Diggs, G. A., Garrison-Wade, D. F., Estrada, D., \& Galindo, R. (2009). Smiling faces and colored spaces: The experiences of faculty of color pursing tenure in the academy. The Urban Review, 41(4), 312.

Evans, S. Y. (2007). Women of colour in American higher education. The National Education Association Thought and Action Higher Education Journal, pp. 131-138. Retrieved from: http://ftp.arizonaea.org/assets/docs/TAA_07_13.pdf

Gooden, A. \& Crawford, C. (2016). Teaching Black Canada(s) Across Borders: Insights from the Caribbean and United States. The Southern Journal of Canadian Studies, Vol. 7. Retrieved from: https://ojs.library.carleton.ca/index.php/sjcs/article/view/1169/1056

Gregory, S. T. (2001). Black women in the academy: Challenges and opportunities. Journal of Negro Education, 70(3), 124-138. Retrieved from: http://www.jstor.org/stable/3211205

Cultural and Pedagogical Inquiry, Summer 2020, 12(1), pp. 91-104

ISSN 1916-3460 @ 2020 University of Alberta

http://ejournals.library.ualberta.ca/index.php/cpi/index 
Harley, D. A. (2008). Maids of academe: African American women faculty at predominately white institutions. Journal of African American Studies, 12(1), 19-36.

Harris, T. M. (2007). Black feminist thought and cultural contracts: Understanding the intersection and negotiation of racial, gendered, and professional identities in the academy. New Directions for Teaching and Learning, 2007(110), 55-64.

Henry, F., Dua, E., James, C. E., Kobayashi, A., Li, P., Ramos, H., \& Smith, M. S. (2017). The equity myth: Racialization and Indigeneity at Canadian universities. Toronto, ON: UBC Press.

Hill Collins, P. (2002). Black feminist thought: Knowledge, consciousness, and the politics of empowerment (2nd Edition). Routledge.

James, J., \& Farmer, R. (1993). Spirit, Space \& Survival: African American women in (White) academe. New York, NY Routledge.

Kobayashi, A. (2009). Now you see them, how you see them: Women of colour in Canadian academe. In F. Henry and C. Taylor (Ed.), Racism in the Canadian University: Demanding social justice, inclusion, and equity (pp. 60-75). Toronto, ON: University of Toronto Press.

Lindholm, J. A. (2003). Perceived organizational fit: Nurturing the minds, hearts, and personal ambitions of university faculty. The Review of Higher Education, 27(1), 125-149.

Massaquoi, N. (2004). An African child becomes a Black Canadian feminist: Oscillating identities in the Black diaspora. Canadian Woman Studies, 23(2), 140.

McLane-Davison, D. R., Quinn, C. R., Hardy, K., \& Smith, R. L. (2018). The Power of sum: An accountability sistah circle. Journal of Social Work Education, 54(1), 18-32.

Mullings \& Mullings-Lewis, R. (2013). How Black mothers "Successfully" raise children in the "Hostile" Canadian climate. Journal of the Motherhood Initiative for Research and Community Involvement, 4(2), 105-119.

National Center for Education Statistics. (2000). Salary, promotion, and tenure status of minority faculty and women faculty in U.S. colleges and universities. Washington, DC: U.S. Department of Education, Office of Educational Research and Improvement. Retrieved from: https://nces.ed.gov/pubs2000/2000173.pdf

Nelson, C. (2012). Resisting invisibility: Black faculty in art and art history in Canada. Equity Matters. Retrieved from: https://www.ideas-idees.ca/blog/resisting-invisibility-blackfaculty-art-and-art-history-canada

Orelus, P. W. (2013). The institutional cost of being a professor of color: Unveiling microaggression, racial [in]visibility, and racial profiling through the lens of critical race theory. Current Issues in Education, 16(2), 1-10.

Razack, S. (1998). Looking white people in the eye: Gender, race, and culture in courtrooms and classrooms. Toronto: ON, University of Toronto Press.

Cultural and Pedagogical Inquiry, Summer 2020, 12(1), pp. 91-104

ISSN 1916-3460 (C) 2020 University of Alberta

http://ejournals.library.ualberta.ca/index.php/cpi/index 
Schiller, N. (2000). A short history of Black feminist scholars. The Journal of Blacks in Higher Education (29), 119-125.

Shealey, M. W., McHatton, P. A., McCray, E., \& Thomas, U. (2014). "Sista doctas" Taking a seat at the table: Advocacy and agency among women of color in teacher education. NASPA Journal About Women in Higher Education, 7(1), 19-46. doi:10.1515/njawhe-2014-0003

Smith, M. (February 2018). Leadership diversity matters at Canada's U15 research-intensive universities. Academic Women's Association University of Alberta. Retrieved from: https://uofaawa.wordpress.com/awa-diversity-gap-campaign/the-diversity-gap-inuniversity-leadership-2018/

Stein, S. (2018). Confronting the radical-colonial foundations of US higher education. Journal for the Study of Postsecondary and Tertiary Education, 3, 77-96. https://doi.org/10.28945/4105

Sudbury, J. (2002). Celling black bodies: Black women in the global prison industrial complex. Feminist Review, 70(1), 57-74.

Thomas, G. D., \& Hollenshead, C. (2001). Resisting from the margins: The coping strategies of Black women and other women of color faculty members at a research university. Journal of Negro Education, 166-175.

Turner, C. S. V. (2002). Women of color in academe: Living with multiple marginality. The Journal of Higher Education, 73(1), 74-93.

Wane, N. N. (Thurs., March 8, 2012). Status of Black women in the academy on International Women's Day. Equity Matters. Retrieved from: https://www.ideas-idees.ca/blog/statusblack-women-academy-international-womens-day

West, C. M. (1995). Mammy, Sapphire, and Jezebel: Historical images of Black women and their implications for psychotherapy. Psychotherapy: Theory, Research, Practice, Training, $32(3), 458$.

Williams, C. C. (2001). The angry Black woman scholar. NWSA Journal, 13(2), 87-97.

Zabrodska, K., \& Kveton, P. (2013). Prevalence and forms of workplace bullying among university employees. Employee Responsibilities and Rights Journal, 25(2), 89-108.

Cultural and Pedagogical Inquiry, Summer 2020, 12(1), pp. 91-104

ISSN 1916-3460 @ 2020 University of Alberta

http://ejournals.library.ualberta.ca/index.php/cpi/index 